\title{
Effects of wilted grass silages varying in fermentation quality on rumen fermentation of dairy cows
}

\author{
E. Saarisalo ${ }^{1,3}$, E. Skyttä ${ }^{2}$ and S. Jaakkola ${ }^{1}$ \\ ${ }^{1}$ Animal Production, MTT Agrifood Research Finland \\ FI-31600 Jokioinen, Finland \\ ${ }^{2}$ Biotechnology, VTT \\ P.O.Box 1500, FI-02044 VTT, Finland
}

\begin{abstract}
Four wilted grass silages (dry matter $280 \mathrm{~g} \mathrm{~kg}^{-1}$ ) varying in fermentation type were fed to rumen fistulated dairy cows to study the effect of silages on rumen fermentation. All additive treatments improved silage quality compared to untreated silage. Formic acid treated, restrictively fermented silage resulted in increased proportion of acetate, while the silages treated with Lactobacillus plantarum increased proportion of propionate of rumen volatile fatty acids.
\end{abstract}

KEY WORDS: wilted silage, Lactobacillus plantarum, potassium sorbate, rumen fermentation

\section{INTRODUCTION}

Inoculation using Lactobacillus plantarum VTT E-78076 (E76) has resulted in efficient lactic acid fermentation, low $\mathrm{pH}$ and small proportion of $\mathrm{NH}_{4}-\mathrm{N}$ in wilted grass silage. However, E76 silage has been prone to aerobic deterioration. In laboratory scale silos aerobic stability has been enhanced by potassium sorbate (E202) (Saarisalo et al., 2003a). With unwilted silages an additive affects the type of silage fermentation and consequently the balance of absorbed nutrients and efficiency of animal production (Miettinen, 1997; Huhtanen, 1998). Wilting as such restricts silage fermentation. This experiment was conducted to study the effects of silage additives used for wilted silages on rumen fermentation.

\section{MATERIAL AND METHODS}

Four silages were made from first cut timothy-meadow fescue ley wilted for 6-15 $\mathrm{h}$ and ensiled in bunker silos. The grass dry matter (DM) was $291 \mathrm{~g} \mathrm{~kg}^{-1}$

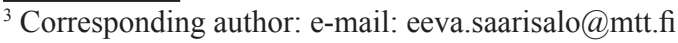


and it contained crude protein 139, water-soluble carbohydrates (WSC) 131 and NDF $555 \mathrm{~g} \mathrm{~kg}^{-1} \mathrm{DM}$. The four additive treatments were: 1. No additive (NO), 2. $\operatorname{AIV}^{\circledR} 2000\left(5.41 \mathrm{t}^{-1}\right.$, formic acid 550 , ammonium formate 240 , propionic acid 50, benzoic acid 10, ethyl benzoate $10 \mathrm{~g} \mathrm{~kg}^{-1}$, Kemira Chemicals Ltd) (FA), 3 . Lactobacillus plantarum VTT-E78076 (E76), and 4. E76 + potassium sorbate 300 $\mathrm{g} \mathrm{t}^{-1}$ (E76S). The target level of the inoculant addition was $10^{6} \mathrm{cfu} \mathrm{g}^{-1}$ grass.

In the physiological study four rumen fistulated dairy cows were used in a balanced $4 \times 4$ Latin square design with periods of 14 days. Silage was given ad libitum and concentrate $10 \mathrm{~kg} \mathrm{~d}^{-1}$ in four portions (barley 324.5, oats 324.5, sugar beet pulp 150, rapeseed meal 170 and minerals $31 \mathrm{~g} \mathrm{~kg}^{-1}$; crude protein 166, starch 347 and NDF 209 $\mathrm{g} \mathrm{kg}^{-1} \mathrm{DM}$ ). Intake and milk production data from the last six days of each period were used. Rumen fermentation samples were collected on day 13 every $1.5 \mathrm{~h}$ from 6.00 to 18.00. Silage, milk and rumen fluid samples were analysed according to the standard procedures of the Animal Nutrition laboratory of MTT.

Intake and milk production data and the daily means of rumen fermentation parameters were tested using the SAS GLM procedure using a model including animal, period and diet. The sums of squares for diet effects were further separated by using orthogonal contrasts into single degree of freedom comparisons: 1 . NO vs additives, 2. FA vs E76 and E76S, 3. E76 vs E76S. The rumen fermentation data were tested also with MIXED procedure with a model including sampling time, time $\times$ period and time $\times$ diet interactions.

\section{RESULTS AND DISCUSSION}

In vitro organic matter digestibility of silages was $760 \mathrm{~g} \mathrm{~kg}^{-1} \mathrm{DM}$. Fermentation quality of the silages was good except for $\mathrm{NO}$ with increased amount of $\mathrm{NH}_{4}-\mathrm{N}$ (Table 1). However, there was a clear difference in the type of fermentation. Proportion of lactic acid of total acids was 0.81, 0.77, 0.91 and 0.91 in NO, FA, E76 and E76S, respectively. Fermentation was most extensive in NO resulting in least WSC (27.4 $\left.\mathrm{g} \mathrm{kg}^{-1} \mathrm{DM}\right)$ and most acetic acid, butyric acid and ethanol $\left(17.5,1.0\right.$ and $11.0 \mathrm{~g} \mathrm{~kg}^{-1}$ DM). FA restricted fermentation resulting in highest amount of WSC $\left(94.2 \mathrm{~g} \mathrm{~kg}^{-1}\right.$ DM). Silage $\mathrm{pH}$ was 0.3 units lower with the inoculants than with NO or FA. Based on small proportions on $\mathrm{NH}_{4}-\mathrm{N}$ in E76 and E76S, lactic acid production was fast in the beginning of the ensiling process as has been observed in laboratory scale experiments with E76 (Saarisalo et al., 2003a). Similar fermentation quality of E76 and E76S indicates that potassium sorbate had no effect on the activity of inoculant.

On average silage intake was $12.2 \mathrm{~kg} \mathrm{DM} \mathrm{d}^{-1}$ and there were no differences between the silages. Extensive secondary fermentation and formation of $\mathrm{NH}_{4}$ $\mathrm{N}$ generally decrease silage intake (Huhtanen, 1998). Wilting as such restricts fermentation and therefore differences between additives are likely to be smaller with wilted silages. 
Table 1 . Fermentation quality of silages, feed intake, milk production and rumen fermentation of dairy cows

\begin{tabular}{|c|c|c|c|c|c|c|c|c|}
\hline \multirow[b]{2}{*}{ Indices } & \multicolumn{4}{|c|}{ Silage $^{1}$} & \multirow[b]{2}{*}{ SEM } & \multicolumn{3}{|c|}{ Statistical significance $^{2}$} \\
\hline & NO & FA & E76 & E76S & & $\begin{array}{c}\text { NO } \\
\text { vs others }\end{array}$ & $\begin{array}{l}\text { FA vs } \\
\text { E76's }\end{array}$ & $\begin{array}{c}\text { E76 vs } \\
\text { E76S }\end{array}$ \\
\hline Dry matter, $\mathrm{g} \mathrm{kg}^{-1}$ & 280 & 301 & 280 & 261 & & & & \\
\hline $\mathrm{pH}$ & 4.20 & 4.17 & 3.92 & 3.90 & & & & \\
\hline $\mathrm{WSC}^{3}, \mathrm{~g} \mathrm{~kg}^{-1} \mathrm{DM}$ & 27.4 & 94.2 & 50.9 & 54.6 & & & & \\
\hline Lactic acid, $\mathrm{g} \mathrm{kg}^{-1} \mathrm{DM}$ & 82.4 & 51.0 & 102.6 & 108.3 & & & & \\
\hline Ethanol, $\mathrm{g} \mathrm{kg}^{-1} \mathrm{DM}$ & 11.03 & 2.20 & 4.28 & 5.13 & & & & \\
\hline Acetic acid, $\mathrm{g} \mathrm{kg}^{-1} \mathrm{DM}$ & 17.47 & 13.51 & 8.53 & 8.71 & & & & \\
\hline $\begin{array}{l}\text { Propionic acid, } \mathrm{g} \mathrm{kg}^{-1} \\
\text { DM }\end{array}$ & 0.39 & 0.75 & 0.61 & 0.35 & & & & \\
\hline Butyric acid, $\mathrm{g} \mathrm{kg}^{-1} \mathrm{DM}$ & 1.00 & 0.45 & 0.74 & 0.82 & & & & \\
\hline $\mathrm{NH}_{4}-\mathrm{N}, \mathrm{g} \mathrm{kg}^{-1} \mathrm{~N}$ & 83.0 & $75.3^{4}$ & 30.5 & 28.5 & & & & \\
\hline \multicolumn{9}{|l|}{ Intake, $\mathrm{kg} \mathrm{DM} \mathrm{d}^{-1}$} \\
\hline silage & 12.3 & 12.1 & 12.2 & 12.2 & 0.52 & & & \\
\hline concentrate & 8.4 & 8.4 & 8.4 & 8.3 & 0.07 & & & \\
\hline Milk, $\mathrm{kg} \mathrm{d}^{-1}$ & 27.6 & 26.9 & 27.9 & 28.2 & 0.65 & & & \\
\hline Energy corr. milk, $\mathrm{kg} \mathrm{d}^{-1}$ & 27.4 & 28.0 & 28.1 & 28.8 & 0.42 & & & \\
\hline \multicolumn{9}{|l|}{ Milk composition, $\mathrm{g} \mathrm{kg}^{-1}$} \\
\hline fat & 41.9 & 44.6 & 42.2 & 43.3 & 0.87 & & & \\
\hline protein & 32.7 & 33.1 & 32.6 & 33.0 & 0.25 & & & \\
\hline lactose & 47.7 & 48.0 & 47.8 & 47.8 & 0.11 & & & \\
\hline urea $\mathrm{mg} \mathrm{dl}^{-1}$ & 22.4 & 20.2 & 22.6 & 24.2 & 0.53 & & $* *$ & o \\
\hline \multicolumn{9}{|l|}{ Rumen fermentation } \\
\hline $\mathrm{pH}$ & 6.31 & 6.34 & 6.25 & 6.34 & 0.05 & & & \\
\hline $\mathrm{NH}_{4}, \mathrm{mmol} \mathrm{l}^{-1}$ & 5.91 & 7.12 & 7.98 & 8.03 & 0.72 & o & & \\
\hline VFA, mmol l-1 & 107.2 & 104.2 & 107.0 & 107.3 & 1.32 & & & \\
\hline \multicolumn{9}{|l|}{ mmol mol-1 VFA } \\
\hline acetate & 626 & 645 & 629 & 624 & 3.1 & & $* *$ & \\
\hline propionate & 197 & 180 & 201 & 208 & 3.9 & & $* *$ & \\
\hline butyrate & 134 & 136 & 131 & 131 & 3.7 & & & \\
\hline
\end{tabular}

${ }^{1}$ NO: no additive, FA: formic acid based additive $5.41 \mathrm{t}^{-1}$, E76: Lact. plantarum VTT E-78076, E76S: E76 + potassium sorbate $0.30 \mathrm{~kg} \mathrm{t}^{-1}{ }^{2}{ }^{2}$ significance: o $(\mathrm{P}<0.10) ;{ }^{*}(\mathrm{P}<0.05)$; ${ }^{* *}(\mathrm{P}<0.01)$;

${ }^{3}$ water soluble carbohydrates; ${ }^{4} 31.3$ when corrected with the amount added in the additive

Energy corrected milk yield was smaller with NO than with treated silages (27.4 vs 28.3). However, the difference was not statistically significant $(\mathrm{P}=0.13)$. Numerically milk fat, protein and lactose concentrations increased with FA compared with inoculated silages $(\mathrm{P}>0.05)$. Likewise in the production trial with the same silages FA tended to increase fat and protein concentrations $(\mathrm{P}<0.10$; Saarisalo et al., 2003b). 
Despite substantial difference in silage $\mathrm{pH}$, rumen $\mathrm{pH}$ (on average 6.31) was not affected by diet, probably due to buffering capacity of saliva. Time $\mathrm{x}$ diet interaction was not significant for the rumen parameters except for the proportion of butyrate. Diurnal variation was very small with inoculated silages while with $\mathrm{NO}$ and FA butyrate proportion was low before feeding but rapidly increased above the levels of E76 and E76S after feeding.

Proportion of acetate was smaller with inoculants than with FA (627 vs $645 \mathrm{mmol}$ $\mathrm{mol}^{-1} ; \mathrm{P}>0.01$ ) while the opposite was observed for propionate $\left(205 \mathrm{vs} 180 \mathrm{mmol} \mathrm{mol}^{-1}\right.$; $\mathrm{P}>0.01$ ). Probably lactic acid of silage was transformed into propionate in rumen (Jaakkola and Huhtanen, 1992). Acetate and butyrate absorbed from the rumen are used for milk fat synthesis. Propionate is needed for gluconeogenesis and synthesis of milk lactose. If there is not enough propionate available, amino acids are used for gluconeogenesis (Huhtanen, 1998).

\section{CONCLUSIONS}

All the treatments improved fermentation quality of silage compared with the untreated. Potassium sorbate had no effect on function of inoculant.

Rumen fermentation was affected by the type of silage, which explains results of production trials. Inoculated silages with increased amounts of lactic acid increase proportion of propionate needed for gluconeogenesis. Restrictively fermented silage high in WSC produced more precursors for milk fat synthesis.

\section{REFERENCES}

Huhtanen P., 1998. Supply of nutrients and productive responses in dairy cows given diets based on restrictively fermented silage. Agr. Food Sci. Finland 7, 219-250

Jaakkola S., Huhtanen P., 1992. Rumen fermentation and microbial protein synthesis in cattle given increasing levels of lactic acid with grass silage based diets. J. Agr. Sci. 119, 411-418

Miettinen H., 1997. Effects of nutrient supply, especially volatile fatty acids, on blood metabolites, mammary nutrient metabolism and milk production in dairy cows. Academic Dissertation, Yliopistopaino, Helsinki

Saarisalo E., Jaakkola S., Vaari A., Skyttä E., 2003a. Effect of inoculant application rate and potassium sorbate on fermentation quality and aerobic stability of wilted grass silages. In: Proceedings of $11^{\text {th }}$ International Scientific Symposium - Forage Conservation. Research Insttitute of Animal Production, Nitra (Slovakia)

Saarisalo E., Jaakkola S., Vaari A., Skyttä E., 2003b. Effect of protein supplementation of wilted silages varying in fermentation quality on milk production. In: O. Niemeläinen, M. Topi-Hulmi (Editors). Proceedings of NJF's 22nd Congress 'Nordic Agriculture in Global Perspective'. Turku (Finland) 